\title{
PENGARUH PENYULUHAN ADAPTASI KEBIASAAN BARU BAGI IBU HAMIL DI POLIKLINIK KEBIDANAN RSUD ULIN BANJARMASIN
}

\author{
Renny Aditya
}

Divisi Obstetri \& Ginekologi Sosial Fakultas Kedokteran ULM RSUD Ulin Banjarmasin

rennyaditya@gmail.com

\begin{abstract}
ABSTRAK
Coronavirus disease 2019 (Covid-19) adalah penyakit yang sedang mewabah hampir di seluruh dunia saat ini, dengan nama virus Severe Acute Respiratory Syndrome Coronavirus-2 (Sars-Cov2). Penyakit ini pertama kali dilaporkan pada 31 Desember 2019. Pada ibu hamil penyakit Covid-19 ini tentunya menjadi perhatian khusus. Perhimpunan Obstetri dan Ginekologi Indonesia (POGI) menyerukan keamanan bagi bu hamil, ibu menyusui, bayi serta anak-anak dari pandemi Covid-19 masih mengancam semua orang. Wanita hamil dan bayi yang baru lahir seharusnya dianggap sebagai populasi berisiko utama dalam strategi yang berfokus pada pencegahan dan manajemen Infeksi Covid19 ini. Penyuluhan ini bertujuan untuk mengetahui pengaruhnya terhadap adaptasi kebiasaan baru bagi ibu hamil di Poliklinik Kebidanan Di RSUD Ulin Banjarmasin melalui metode ceramah kelompok, dilakukan teknik pra-eksperimental dengan pendekatan one group pretest-posttest design. Besar sampel penelitian adalah 25 responden dengan teknik purposive sampling. Analisis data menggunakan uji Wilcoxon dan t berpasangan. Metode penyuluhan ini melalui ceramah kepada kelompok ibu hamil yang melakukan antenatal care. Hasil penyuluhan memberikan pengaruh tentang adaptasi kebiasaan baru bagi ibu hamil terhadap tingkat pengetahuan ( $p$ value $=0.005)$ dan sikap $(p$ value $=0.003)$.
\end{abstract}

Kata-kata kunci: adaptasi, Covid-19, ibu hamil, kebiasaan baru, penyuluhan

\section{PENDAHULUAN}

Pertengahan tahun 2020, pandemic Covid-19 belum juga berakhir. Masyarakat Indonesia diimbau untuk menerapkan adaptasi kebiasaan baru agar dapat hidup produktif dan tetap terhindar dari penularan virus yang sudah menelan lebih dari 500 ribu korban jiwa ini. Saat ini, pemerintah Republik Indonesia tidak lagi menggunakan istilah "new normal” yang kerap digunakan selama pandemi Covid-19 Istilah tersebut telah diganti menjadi "adaptasi kebiasaan baru" atau AKB. Pada era ini, masyarakat bisa beraktivitas kembali secara produktif, namun tetap menerapkan Covid-19. 1,2,3 Penyuluhan kesehatan adalah kegiatan pendidikan yang dilakukan dengan cara menyebarkan pesan menanamkan keyakinan sehingga masyarakat tidak saja sadar, tahu dan mengerti, tetapi juga mau dan bisa melakukan suatu anjuran adaptasi kebiasaan baru ${ }^{3,4-7}$

Sasaran penyuluhan kesehatan adalah individu, keluarga, kelompok dan masyarakat memlalui metode ceramah, oleh karena metode ini baik untuk sasaran yang berpendidikan tinggi maupun rendah, yang dijadikan subjek dan objek perubahan perilaku, sehingga diharapkan dapat 
memahami, menghayati dan mengaplikasikan cara-cara hidup sehat dan kehidupan sehariharinya dalam menghadapi pandemi Covid19. 8,9 Penyuluhan dengan metode ceramah ini bertujuan untuk mengetahui pengaruh penyuluhan tentang adaptasi kebiasaan baru bagi ibu hamil di Poliklinik Kebidanan Di RSUD Ulin Banjarmasin

\section{METODE}

Untuk menilai hasil penyuluhan maka dilakukan teknik pra-eksperimental dengan pendekatan one group pretest-posttest design. Besar sampel penelitian adalah 25 responden ibu hamil yang datang untuk melakukan antenatal care yang diambil secara purposive sampling dan diberikan metode ceramah selama 1 jam dengan diskusi tentang adaptasi kebiasaan baru bagi ibu hamil dengan protokol kesehatan. Penyuluhan dilakukan di Poliklinik Kebidanan RSUD Ulin Banjarmasin dengan protokol kesehatan. Analisis data menggunakan uji Wilcoxon dan $t$ berpasangan.

\section{HASIL DAN PEMBAHASAN}

\section{A. Analisis Univariat}

Responden diberikan pretest dan post test dengan hasil sebagai berikut :

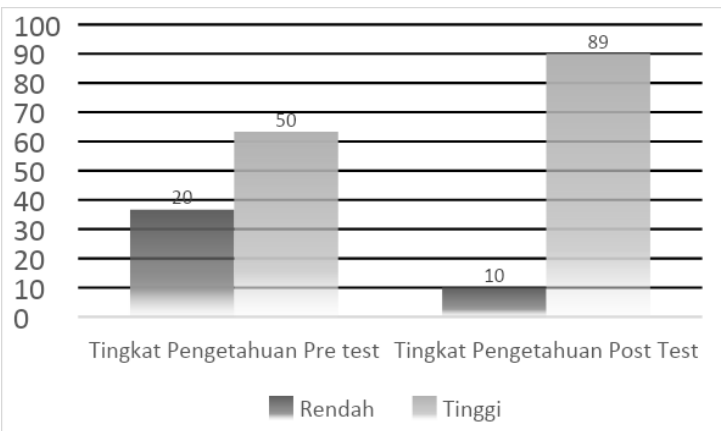

Gambar 1. Gambaran Tingkat Pengetahuan Responden Pada Pre Test dan Postest
Pada gambar 1 diketahui bahwa tingkat pengetahuan responden pada saat pre test yaitu sebanyak $20 \%$ berpengetahuan rendah dan 50\% berpengetahuan tinggi dan adaptasi kebiasaan baru bagi ibu hamil terjadi peningkatan pengetahuan yaitu pengetahuan tinggi menjadi $89 \%$ responden dan pengetahuan rendah berkurang jadi $10 \%$ responden.

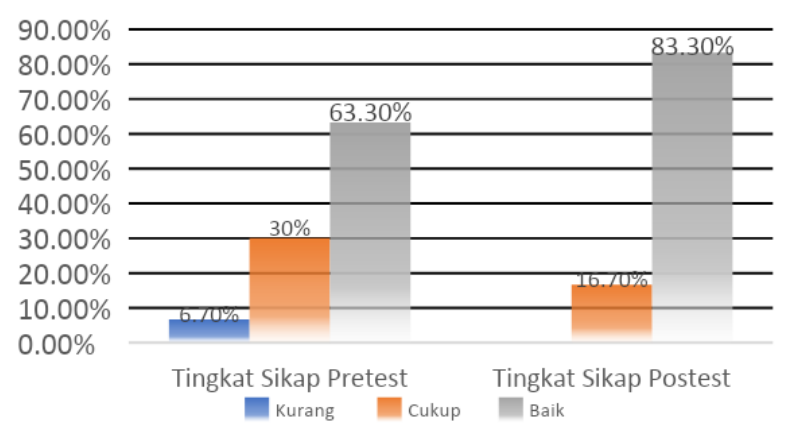

Gambar 2. Tingkat Sikap Responden pada saat pretest dan postest

Berdasarkan gambar 2 diketahui pada saat sebelum adalah $6,7 \%$ responden bersikap kurang, $30 \%$ responden bersikap cukup dan 63,3\% responden bersikap baik. Setelah dilakukan pelatihan terjadi peningkatan sikap responden mengenai adaptasi kebiasaan baru bagi ibu hamil di Poliklinik Kebidanan Di RSUD Ulin Banjarmasin yaitu 16,7\% responden bersikap cukup dan $83,3 \%$ responden mempunyai sikap yang baik.

Hasil dari pretest dan postest pengetahuan dan sikap menunjukkan bahwa penyuluhan adaptasi kebiasaan baru bagi ibu hamil di Poliklinik Kebidanan Di RSUD Ulin Banjarmasin dapat meningkatkan pengetahuan dan sikap responden menjadi baik.

Analisis data menggunakan uji Wilcoxon dan $\mathrm{t}$ berpasangan. Hasil penelitian ini menunjukkan adanya pengaruh penyuluhan terhadap tingkat pengetahuan $(p$ value $=0.005)$ dan sikap $(p$ value $=0.003)$. 


\section{B. Analisis Bivariat}

1. Perbedaan Pengetahuan Sebelum dan Sesudah penyuluhan adaptasi kebiasaan baru bagi ibu hamil

Hasil analisis dengan uji paired $t$ test menunjukkan hasil sebagai pada tabel 1.1 yaitu :

Tabel 1.1 Hasil Analisis Pengetahuan Responden Sebelum dan Sesudah Intervensi penyuluhan

\begin{tabular}{l|l|l|l|l}
\hline No & Variabel & Mean & $\boldsymbol{p}$-value & Ket \\
\hline 1 & Pre test & 5,64 & 0,005 & $\begin{array}{l}\text { Terdapat } \\
\text { perbedaan } \\
\text { yang } \\
\text { signifikan }\end{array}$ \\
\hline 2 & Post test & 8,83 & \\
\hline
\end{tabular}

Berdasarkan tabel 1.1 diketahui rata-rata pengetahuan responden sebelum penyuluhan sebesar 5,64 dan setelah mendapatkan intervensi rata-rata pengetahuan responden meningkat menjadi 8,83. Hasil uji paired t test menunjukkan nilai $p$-value 0,0001 artinya terdapat perbedaan yang siginifikan pengetahuan sebelum dan sesudah penyuluhan.

2. Perbedaan Sikap Sebelum dan Sesudah penyuluhan adaptasi kebiasaan baru bagi ibu hamil di Poliklinik Kebidanan Di RSUD Ulin Banjarmasin

Hasil analisis sikap responden dengan uji paired $t$ test menunjukkan hasil sebagai pada Tabel 1.2 yaitu :

Tabel 1.2 Hasil Analisis Sikap Responden Sebelum dan Sesudah Intervensi penyuluhan

\begin{tabular}{l|l|l|l|l}
\hline No & Variabel & Mean & p-value & Ket \\
\hline 1 & Pre test & 47,50 & 0,003 & $\begin{array}{l}\text { Terdapat } \\
\text { perbedaan } \\
\text { yang } \\
\text { signifikan }\end{array}$ \\
\hline 2 & Post test & 70,13 & & \\
\hline
\end{tabular}

Berdasarkan tabel 1.2 diketahui rata-rata sikap responden sebelum penyuluhan adaptasi kebiasaan baru sebesar 47,50 dan setelah mendapatkan intervensi rata-rata sikap responden meningkat menjadi 70,13. Hasil uji paired $t$ test menunjukkan nilai $p$-value 0,003 artinya terdapat perbedaan yang siginifikan terhadap sikap sebelum dan sesudah intervensi penyuluhan.

Penyuluhan dengan metode ceramah adalah pidato yang disampaikan oleh seorang pembicara di depan sekelompok pengunjung. Ceramah pada hakikatnya adalah proses transfer informasi dari pengajar kepada sasaran belajar. Dalam proses tranfer informasi ada tiga elemen penting, yaitu pengajar, materi dan sasaran belajar. Metode ceramah efektif digunakan untuk meningkatkan pengetahuan seseorang. Ceramah digunakan pada sifat sasaran sebagai berikut, yaitu sasaran belajar mempunyai perhatian yang selektif, sasaran belajar mempunyai lingkup perhatian yang terbatas, sasaran belajar memerlukan informasi yang kategoris dan sistematis, sasaran belajar perlu menyimpan informasi, sasaran belajar perlu menggunakan informasi yang diterima. Adapun kelebihan menggunakan metode ceramah antara lain : dapat digunakan pada orang dewasa, penggunaan waktu yang efisien, dapat dipakai pada kelompok yang besar, tidak terlalu banyak menggunakan alat bantu pengajaran, dapat dipakai untuk memberi pengantar pada pelajaran atau suatu kegiatan. ${ }^{9,10}$

\section{KESIMPULAN}

1. Terdapat peningkatan pengetahuan \& sikap responden adaptasi kebiasaan baru bagi ibu hamil di Poliklinik Kebidanan di RSUD Ulin Banjarmasin.

2. Penyuluhan dengan metode ceramah tentang dapat meningkatkan pengetahuan dan sikap responden menjadi lebih baik 
adaptasi kebiasaan baru bagi ibu hamil di Poliklinik Kebidanan Di RSUD Ulin Banjarmasin

\section{REFERENSI}

1. Kemenkes RI. Menuju Adaptasi Kebiasaan Baru. Direktorat Jendral Pencegahan dan Pengendalian Penyakit. 2020

2. Burhan E, Isbaniah F, Susanto AD, Aditama TY, Soedarsono, dkk. Pneumonia COVID-19 "Diagnosis \& Penatalaksanaan di Indonesia". Perhimpunan Dokter Paru Indonesia. 2020.

3. WHO. Pencegahan dan pengendalian Infeksi (PPI) untuk Novel Coronavirus (COVID-19). WHO. 2020.

4. Gugus Tugas Percepatan Penanganan COVID-19. Situasi COVID-19 di Indonesia. Available at: https://www.covid19.go.id/ diakses tanggal 1 Juli 2020

5. Worldometer COVID-19 Data. Available

athttps://www.worldometers.info/cor onavirus/ diakses tanggal 1 Juli 2020

6. Wantania J, Yeni CM, Sitepu M, et al. Rekomendasi Penanganan Infeksi Virus Corona (COVID-19) Pada Maternal (Hamil, Bersalin, Nifas). Pokja Infeksi Saluran Reproduksi Perkumpulan Obstetri dan Ginekologi Indonesia. 2020.

7. Keputusan Menteri Kesehatan Republik Indonesia Nomor HK.01.07/Menkes/413/2020 tentang Pedoman Pencegahan dan Pengendalian Corona Virus Disease 2019 (COVID 19).

8. Protokol Petunjuk Praktis Layanan Kesehatan Ibu dan Bayi Baru Lahir
Selama Pandemi Nomor : B4 (05 April 2020).

9. Notoatmodjo, Soekidjo. 2007. Pendidikan dan Promosi Kesehatan. Jakarta: Rineka Cipta.

10. Setiana, 2005. Teknik Penyuluhan dan Pemberdayaan Masyarakat. Bogor: Ghalia Indonesia. 